\title{
Effects of Glycerophospholipids on Ceramide Kinase Activity: Cardiolipin-Affected Cellular Formation of Ceramide-1-phosphate
}

\author{
Wataru Matsuzaki, ${ }^{\text {Hiromasa Takahashi, }}$ Hiroyuki Nakamura, ${ }^{*}$ and Toshihiko Murayama \\ Laboratory of Chemical Pharmacology, Graduate School of Pharmaceutical Sciences, Chiba University; Chiba \\ 260-8675, Japan. \\ Received July 4, 2016; accepted July 29, 2016
}

Ceramide kinase (CerK) and ceramide-1-phosphate (C1P) are involved in various cellular functions, while regulation of the enzyme activity has not been well elucidated. We herein investigated the effects of several glycerophospholipids on human recombinant $\mathrm{CerK}$ activity with $\mathrm{CaCl}_{2}$ and $\mathrm{MgCl}_{2}$ by measuring the formation of fluorescent labeled $\mathrm{C} 1 \mathrm{P}$ in vitro. CerK activities were $44.1 \pm 11.4(\mathrm{pmol} / \mu \mathrm{g} / \mathrm{min})$ with vehicle, $137 \pm 29$ with $2 \mathrm{mM} \mathrm{CaCl}_{2}$, and $144 \pm 32$ with $2 \mathrm{mM} \mathrm{MgCl}_{2}$ in the glycerol/albumin buffer. The addition of glycerophospholipids such as phosphatidylcholine, phosphatidylinositol (PI), PI 4,5-bisphosphate $\left(\mathrm{PI}(4,5) \mathrm{P}_{2}\right)$, and phosphatidic acid had no effect on CerK activity with $\mathrm{CaCl}_{2}$, although $\mathrm{PI}(4,5) \mathrm{P}_{2}$ and phosphatidic acid bound to CerK in the lipid-protein overlay assay. The addition of cardiolipin (diphosphatidylglycerol) at concentrations up to $0.1 \mu \mathrm{M}$ increased, whereas those more than $1 \mu \mathrm{M}$ decreased $\mathrm{CerK}$ activity with $\mathrm{CaCl}_{2} / \mathrm{MgCl}_{2}$. In the lipid-protein overlay assay, cardiolipin bound to CerK and CerK lacking pleckstrin homology (PH) domain, but not $\mathrm{PH}$ domain of $\mathrm{CerK}$, in $\mathrm{CaCl}_{2}$-independent manner. Cardiolipin also bound to CerK in the multilamellar vesicle binding assay. A deviation from the normal range of cellular cardiolipin, both the decrease by phospholipase D6 expression and increase by an exogenous addition of the lipid, negatively regulated C1P formation in intact HepG2 cells. Our results revealed that cardiolipin bound to CerK and regulated the formation of $\mathrm{C} 1 \mathrm{P}$ in vitro and in cells.

Key words ceramide kinase; cardiolipin; glycerophospholipid

Ceramide kinase (CerK) produces ceramide-1-phosphate (C1P) through the phosphorylation of ceramide, and the cloning and functional characterization of this enzyme were successfully achieved by Drs. Kohama and Spiegel's group. ${ }^{1)} \mathrm{C} 1 \mathrm{P}$ and ceramide both act as intracellular and extracellular lipid signaling molecules as well as components of biomembrane structures in cells, and the biological and/or cellular roles of CerK and C1P were established before and after the identification of human CerK. ${ }^{2-6)}$ in vitro, CerK activity is dependent on divalent ions, particularly calcium ions.,2,7,8) Treatment with the calcium ionophore A23187 was reported to increase CerK activity and/or C1P formation in A549 carcinoma cells, ${ }^{9}$ RBL-2H3 cells, ${ }^{10)}$ and CerK-overexpressing Chinese hamster ovary (CHO) cells. ${ }^{11)}$ Thus, $\mathrm{Ca}^{2+}$ ions appeared to be essential for CerK activity or an activator of the enzyme. Cultivation of cells with stimuli such as interleukin- $1 \beta^{9)}$ and serum ${ }^{8)}$ activated CerK activity and/or formation of C1P. Bornancin's group reported that a cluster of Cys residues $\left(\mathrm{C}^{347} \mathrm{XXXC}^{351} \mathrm{XXC}^{354}\right)$ was important for CerK enzyme activity ${ }^{12)}$ and that CerK is a phosphoprotein at least $\operatorname{Ser}^{340}$ and $\operatorname{Ser}^{408}$ residues and phosphorylation of the $\mathrm{Ser}^{340}$ residue impacted stability of the active enzyme conformation. ${ }^{13)}$ Previously, we reported that treatment with orthovanadate, a general inhibitor of tyrosine phosphatase, increased C1P formation via CerK in A549 cells and CHO cells. ${ }^{14)}$ However, precise mechanisms for the posttranslational regulation of CerK activity have not yet been elucidated.

The N-terminus of CerK bears a pleckstrin homology $(\mathrm{PH})$ domain, and this domain is indispensable for its activity and acts as a regulator of its targeting and sub-cellular localiza-

\footnotetext{
${ }^{\#}$ These authors contributed equally to this work.

tion. $^{4,15-18)}$ Like many $\mathrm{PH}$ domain-containing proteins, CerK can bind with high specificity and affinity to certain phosphatidylinositol (PI) phosphates including PI 4,5-bisphosphate $\left(\mathrm{PI}(4,5) \mathrm{P}_{2}\right)$. However, the effects of glycerophospholipids such as $\mathrm{PI}$, phosphatidylcholine, and $\mathrm{PI}(4,5) \mathrm{P}_{2}$ on CerK activity in vitro have not been well established. Cardiolipin (diphosphatidylglycerol), is a unique phospholipid with four acyl chains and two negative charges, and this lipid is generally used to measure CerK activity in vitro.,19-23) However, it currently remains unknown whether cardiolipin directly interacts with and activates CerK. Thus, we investigated the effects of glycerophospholipids including cardiolipin on recombinant human CerK activity in the glycerol/albumin buffer. In the present study, we showed that cardiolipin bound to CerK and regulated its activity in vitro, and that the modification of cellular cardiolipin levels changed the formation of C1P in intact cells.

\section{MATERIALS AND METHODS}

Materials The materials used in this study and their sources were as follows. A fluorescent ceramide, 4-nitrobenzo2-oxa-1,3-diazole-labeled C6-ceramide (NBD-ceramide) was purchased from Molecular Probes (Eugene, OR, U.S.A.); cardiolipin (from bovine heart), glycerol, Triton X-100, and bovine serum albumin (fatty acid-free) were from Sigma-Aldrich (St. Louis, MO, U.S.A.); phosphatidic acid, phosphatidylcholine, phosphatidylethanolamine, phosphatidylserine, and PI were from Matreya LLC (Pleasant Gap, PA, U.S.A.); PI(4,5) $\mathrm{P}_{2}$ (1,2-dipalmitoyl) was from Cayman (Ann Arbor, MI, U.S.A.). Stock solutions of the respective lipids were as follows: cardiolipin (ethanol), glycerophospholipids such as phosphatidylcholine and phosphatidylethanolamine (chloroform-methanol, 
$2: 1, \mathrm{v} / \mathrm{v}), \mathrm{PI}(4,5) \mathrm{P}_{2}$ (distilled water), and NBD-ceramide (dimethyl sulfoxide (DMSO)). In some experiments, cells were cultured with cardiolipin micelles in medium with serum. The cardiolipin micelles were prepared by sonication of medium with cardiolipin for $5 \mathrm{~min}$ in a bath-type sonicator until the mixture becomes a homogenous dispersion. After being cultured for the indicated times, cells were washed with cardiolipin-free medium and then used to measure the formation of NBD-C1P and cellular levels of cardiolipin.

Construction of Plasmids for Recombinant Human CerK and Green Fluorescent Protein (GFP)-Tagged Phospholipase D6 (PLD6, Mitochondrial PLD) and Preparation of CerK cDNA encoding human CerK (a gift from Dr. Kohama, Daiichi-Sankyo, Co., Ltd., Tokyo, Japan) was amplified by PCR using a forward primer 5'-TAA AGGATCCAT GGGGGCGACGGGG-3', and a reverse primer 5'-TAT AGC TCG AGT CAGCTG TGT GAG TCTGG-3'. This amplification product (full-length, 1-537) was cloned into BamHI and XhoI of pGEX-6P-1 vector to generate the glutathione $S$-transferase (GST) fusion construct. Likewise, two deletion mutants: PH domain of CerK (1-124, PH-CerK), and CerK lacking PH domain (125-537, $\triangle \mathrm{PH}-\mathrm{CerK})$ were created using a forward primer 5'-TAAAGGATCCATGGGGGC GACGGGG-3', and a reverse primer 5'-TAT AGCTCGAGT CAC TCC AGC ATC TCCCG-3' for PH-CerK, and a forward primer 5'-TAA AGG ATC CAA GCT GAC GTC CAG A-3', and a reverse primer 5'-TAT AGCTCGAGTCAGCTGTGT GAG TCT GG-3' for $\triangle \mathrm{PH}-\mathrm{CerK}$. cDNA encoding human PLD6 (available from Open Biosystems, MHS6278-202808613) was amplified by PCR using a forward primer, 5'-TATCTC GAGGGCGGCATGGGA CGGTTGAGT-3', and a reverse primer 5'-TTA CTGCAGGGT TTGGCT TTC GCT GGA-3'. This amplification product was cloned into the C-terminally GFP-tagged pEGFP-N1 vector at XhoI/PstI sites to generate the GFP fusion construct. GST-fusion proteins were expressed in the E. coli BL21 (DE3) strain upon incubation with $0.05 \mathrm{~mm}$ isopropyl 1 -thio- $\beta$-D-galactoside (IPTG) and $4 \%$ ethanol at $25^{\circ} \mathrm{C}$ for $16 \mathrm{~h}$ for full-length CerK and $\Delta \mathrm{PH}-\mathrm{CerK}$. For PH-CerK expression, the bacteria were incubated with $0.1 \mathrm{~mm}$ IPTG and $4 \%$ ethanol at $30^{\circ} \mathrm{C}$ for $4 \mathrm{~h}$. The bacteria were centrifuged at $6000 \mathrm{rpm}$ for $15 \mathrm{~min}$. After the bacterial pellet was re-suspended in lysis buffer (PBS containing $1 \mathrm{~mm}$ dithiothreitol, $1 \%$ Triton X-100, 10\% glycerol, $0.5 \mathrm{~mm}$ phenylmethylsulfonyl fluoride (PMSF)), the lysates were sonicated. GST-fusion proteins were collected on glutathione-Sepharose beads from the lysates, washed five times with lysis buffer, and eluted with elution buffer $(20 \mathrm{~mm}$ reduced glutathione, $50 \mathrm{~mm}$ Tris- $\mathrm{HCl}, \mathrm{pH} 8.0$ ).

CerK Activity Assay The activity of recombinant CerK in vitro with $10 \mu \mathrm{M}$ NBD-ceramide was measured in the two buffers, as described previously ${ }^{20,22)}$ with modifications. The glycerol/albumin buffer was used to examine the effects of glycerophospholipids including cardiolipin on CerK activity. As described in the Results, supplementation of glycerophospholipids including cardiolipin did not change CerK activity in the cardiolipin/Triton X-100 buffer. To study the $\mathrm{CaCl}_{2} / \mathrm{MgCl}_{2}$ responsibility on CerK activity, both the glycerol/albumin buffer and cardiolipin/Triton X-100 buffer were used. The assays using the glycerol/albumin buffer were performed as follows. NBD-ceramide and cardiolipin were directly added to the reaction buffer $(90 \mu \mathrm{L})$. CerK $(30 \mathrm{ng} /$ tube, $10 \mu \mathrm{L})$ was added to the assay mixtures (total volume $100 \mu \mathrm{L}$ ), and incubated at $37^{\circ} \mathrm{C}$ for $15 \mathrm{~min}$. The assay mixture consisted of $10 \%$ glycerol, $0.02 \%$ albumin, $100 \mathrm{~mm} \mathrm{KCl,} 1 \mathrm{~mm}$ dithiothreitol, $1 \mathrm{~mm}$ ATP, $40 \mathrm{~mm} N$-(2-hydroxyethyl)piperazine- $N$ '-2-ethanesulfonic acid (HEPES) ( $\mathrm{pH} \mathrm{7.4),} \mathrm{CaCl}_{2}$, and/or $\mathrm{MgCl}_{2}$ at the indicated concentrations. The assays using the cardiolipin/Triton X-100 buffer were performed as follows. Mixed micelles containing cardiolipin, Triton X-100, and NBD-ceramide were prepared by drying lipids from stock solutions with $\mathrm{N}_{2}$ gas and then sonicating $(3 \mathrm{~min})$ in reaction buffer $(100 \mathrm{~mm} \mathrm{KCl}, 1 \mathrm{~mm}$ dithiothreitol, $1 \mathrm{~mm}$ ATP, $40 \mathrm{~mm}$ HEPES, pH 7.4). The micelles were diluted five-fold with reaction buffer, and $100-\mu \mathrm{L}$ reactions were initiated by the addition of CerK (30 ng), $\mathrm{CaCl}_{2}$, and/or $\mathrm{MgCl}_{2}$. The final concentrations of the reagents in the mixed micelles were: $36 \mu \mathrm{M}$ cardiolipin, $0.0125 \%$ Triton $\mathrm{X}-100$, and $10 \mu \mathrm{M}$ NBD-ceramide. In the two assays, concentration of glutathione derived from CerK preparation was $0.046 \mathrm{~mm}$. In both buffers, the reaction was stopped by the addition of $125 \mu \mathrm{L}$ of chloroform and $250 \mu \mathrm{L}$ of methanol after the incubation. In order to extract C1P to the organic phase, the $\mathrm{pH}$ of the mixture was adjusted to approximately $2-3$ by the addition of $5 \mathrm{~N} \mathrm{HCl}(1 \mu \mathrm{L})$, and the mixtures were vigorously vortexed and incubated at $4^{\circ} \mathrm{C}$ for $10 \mathrm{~min}$. After adding $125 \mu \mathrm{L}$ of chloroform and $125 \mu \mathrm{L}$ of water, the samples were then divided into organic and aqueous phases using centrifugation (3000 rpm, $10 \mathrm{~min})$. NBD-C1P extracted in the organic phase $(100 \mu \mathrm{L})$ was dried under nitrogen. Dried samples were dissolved in $10 \mu \mathrm{L}$ of chloroform-methanol $(1: 1)$ and analyzed on silica gel-60 TLC plate (Merk, Germany). The formation of NBD-C1P was measured for $15 \mathrm{~min}$ at $37^{\circ} \mathrm{C}$, and CerK activity (pmol NBD-C1P/ $\mu$ g CerK protein/min) was examined. In the glycerol/albumin and cardiolipin/Triton X-100 buffers with and without supplements, such as $\mathrm{CaCl}_{2}-\mathrm{MgCl}_{2}$ and the indicated lipids, the formation of NBD-C1P was linear for $30 \mathrm{~min}$ depending on the concentration of CerK from 10 to $30 \mathrm{ng}$ per assay tube.

Lipid-Protein Binding Assays: Overlay Assay and Large Multilamellar Vesicle Binding Assay Assays were performed as previously described ${ }^{24)}$ with minor modifications. Briefly, tested lipids were dissolved in the indicated solvents and spotted onto a Hybond $\mathrm{C}$ membrane (Amersham) in the lipid-protein overlay assay. After drying, the membrane was rewetted and blocked for $1 \mathrm{~h}$ in the TBS/Tween 20 buffer containing $2 \%$ albumin, and then exposed overnight at $4^{\circ} \mathrm{C}$ to respective preparations of GST-tagged recombinant human CerK proteins containing $0.1 \mathrm{mM} \mathrm{CaCl}_{2}$. In some cases, the CerK preparations containing $1 \mathrm{~mm}$ ethylene glycol bis(2aminoethyl ether)- $N, N, N^{\prime}, N^{\prime}$-tetraacetic acid (EGTA) were used. The washed membranes were treated with an anti-GST antibody $(27457701 \mathrm{~V}$, GE Health Care, Buckinghamshire, U.K.), and the immunoreactive spots were visualized using a second antibody. In the vesicle binding assay, vesicles of cardiolipin or phosphatidylcholine were prepared by vigorously vortexing the lipids in the buffer $(50 \mathrm{~mm}$ Tris- $\mathrm{HCl}, \mathrm{pH} 7.4$, $150 \mathrm{~mm} \mathrm{NaCl}, 0.1 \mathrm{~mm} \mathrm{CaCl}_{2}$ ). The binding reaction was initiated by the adding of lipid vesicle solutions and GST-CerK. After $5 \mathrm{~min}$ at room temperature, the reaction mixture was centrifuged at $17000 \times \mathbf{g}$ for $10 \mathrm{~min}$, and the supernatant was removed. After repeated washing and centrifugation, the pellet was subjected to sodium dodecyl sulfate-polyacrylamide gel electrophoresis (SDS-PAGE), and the immunoreactive 
bands to an anti-GST antibody were visualized using a second antibody. In the two assays, purified recombinant GST did not bind to any of the lipids.

Transfection of HepG2 Cells with the PLD6-GFP Vector, and Measurement of PLD6-GFP Expression Regarding protein expression, cells were seeded at a density of $4.5 \times 10^{4}$ cells/well (12-well plate), cultured for $2 \mathrm{~d}$ in Dulbecco's modified Eagle's medium (DMEM) with serum, and transiently transfected with $2 \mu \mathrm{g}$ of expression vectors for Lipofectamine PLUS (Invitrogen) in Opti-MEM without serum, according to the manufacturer's protocol. After a 3-h incubation, transfected cells were further cultured with DMEM with serum for $24 \mathrm{~h}$, and then used in various assays such as the expression of PLD6-GFP, measurement of intracellular cardiolipin levels, and formation of C1P. The expression of PLD6-GFP was confirmed by Western blotting using an anti-GFP antibody (sc-8334, Santa Cruz Biotech. Dallas, TX, U.S.A.). In some cases, transfected cells were seeded on the coverslips $(12 \mathrm{~mm}$ in diameter) of glass-bottomed dishes (Iwaki, Tokyo, Japan). After being cultured for $40-48 \mathrm{~h}$, the cells were washed with buffer and GFP-derived fluorescent images were taken with a FluoView-FV500 confocal laser scanning microscope system (Olympus, Tokyo).

Measurement of Intracellular Cardiolipin Levels Phospholipids including cardiolipin in HepG2 cells expressing PLD6-GFP and cultured with cardiolipin were extracted in chloroform-methanol- $\mathrm{HCl}$ solution as described previously ${ }^{25}$ with minor modifications. The organic fraction after evaporation was separated on silica gel-60 HPTLC plate. The positions of phospholipids such as cardiolipin and PI on the plate after visualization using iodine staining were determined by matching the migration distance to standards and previously reported Rf values. The intensity of iodine staining was measured using NIH ImageJ software.

Measurement of NBD-C1P Formation in HepG2 Cells Cells were incubated with $10 \mu \mathrm{M}$ NBD-ceramide for $30 \mathrm{~min}$ or $1 \mathrm{~h}$, and lipids including NBD-labeled ceramide metabolites in wells (both cells and medium) were extracted by chloroformmethanol. NBD-labeled ceramide metabolites including NBDC1P were separated using TLC, and the levels of metabolites were determined as described previously. ${ }^{14,26,27)}$ Absolute values (pmol/well) of ceramide metabolites in HepG2 cells were similar to those in cells previously reported, ${ }^{14,26,27)}$ and the relative levels of NBD-sphingomyelin, NBD-glucosylceramide, and NBD-C1P at $30 \mathrm{~min}$ after labeling with NBD-ceramide were $5-10$ ( $\%$ of NBD-ceramide), 3-6, and $0.05-0.1 \%$, respectively. Since the ceramide metabolites showed a wide range of values and the absolute values varied depending on experiments, the data in Figs. 4E and 5B were expressed as percentages of the respective metabolites in control cells.

Analysis of Cell Morphology and Cell Detachment Cellular effects induced by modification of cardiolipin levels were examined by cell morphology and cell detachment. The morphological changes of cells at $50-60 \%$ confluence were observed by differential interference contrast microscopy. Cells were cultured with serum at $70-80 \%$ confluence, and cell numbers attached on plates were counted at $24 \mathrm{~h}$ after cardiolipin treatment.

Data Presentation and Statistics Values are the mean \pm standard deviation (S.D.) for the indicated number (n) of independent experiments. The values in Fig. 5 are the mean \pm standard error of the mean (S.E.M.) of three independent experiments performed in duplicate. In the case of multiple comparisons, the significance of differences was determined using a one-way analysis of variance with Dunnett's or Tukey's test. The Student's two-tailed $t$-test was used for pairwise comparisons. $p$ Values $<0.05$ were considered to be significant.

\section{RESULTS}

Roles of $\mathrm{CaCl}_{2}$ and $\mathrm{MgCl}_{2}$ on CerK Activity First, activities of human recombinant CerK were examined with and without $\mathrm{CaCl}_{2}$ and $\mathrm{MgCl}_{2}$. In the glycerol/albumin buffer containing the substrates ( $1 \mathrm{~mm} \mathrm{ATP}$ and $10 \mu \mathrm{M}$ NBD-ceramide), our preparations of recombinant CerK exhibited a marked activity in vitro (Figs. 1A, B, open circles). The activity was $44.1 \pm 11.4 \mathrm{pmol} / \mu \mathrm{g} / \mathrm{min}$ ( $n=7$, Fig. $1 \mathrm{C})$. CerK activity was increased by the addition of $\mathrm{CaCl}_{2}$ and $\mathrm{MgCl}_{2}$, and the addition of $\mathrm{CaCl}_{2}$ and $\mathrm{MgCl}_{2}$ at $0.1 \mathrm{~mm}$ led to almost maximal stimulatory effects on CerK activity (Fig. $1 \mathrm{C}$ ). $\mathrm{CaCl}_{2}$ and $\mathrm{MgCl}_{2}$ at $2 \mathrm{~mm}$ both increased this activity approximately 3-fold over that of control activity. CerK activity was previously reported to increase from 0.1 to $10 \mu \mathrm{M} \mathrm{Ca}{ }^{2+1,3)}$ thus, we investigated the roles of $\mathrm{CaCl}_{2}$ on CerK activity in detail. The activities of CerK with and without $0.1 \mathrm{~mm} \mathrm{CaCl}_{2}$ were almost completely abolished in the presence of $2 \mathrm{~mm}$ EGTA, while those with $2.5 \mathrm{~mm} \mathrm{CaCl}_{2}$ and $0.1 \mathrm{~mm}^{\mathrm{MgCl}_{2}}$ were not modified by EGTA (Fig. 1D). The addition of not only $2 \mathrm{~mm}$ EGTA, but also $2 \mathrm{~mm}$ ethylenediaminetetraacetic acid (EDTA) to the assay mixtures markedly decreased CerK activity (Table 1). The addition of $\mathrm{CaCl}_{2}$ at $10 \mu \mathrm{M}$ did not increase CerK activity (40-50 pmol $/ \mu \mathrm{g} /$ min), whereas $50 \mu \mathrm{M} \mathrm{CaCl}_{2}$ markedly increased CerK activity to approximately half of that with $0.1 \mathrm{~mm}$. The combination of $\mathrm{CaCl}_{2}$ and $\mathrm{MgCl}_{2}$ at $1 \mathrm{~mm}$ did not enhance CerK activity; the value with $\mathrm{CaCl}_{2} / \mathrm{MgCl}_{2}$ were $0.97 \pm 0.12$-fold of that with $\mathrm{MgCl}_{2}$ alone $(n=3)$.

Effects of Glycerophospholipids on CerK Activity Next, we investigated the effects of various glycerophospholipids on CerK activity in the glycerol/albumin buffer. Phosphatidylcholine, phosphatidylethanolamine, PI, and phosphatidylserine at $0.1 \mu \mathrm{M}$ had no significant effect on CerK activity (Table 2). Phosphatidic acid, an acidic glycerophospholipid, at $0.1 \mu \mathrm{M}$ did not change CerK activity. These lipids including phosphatidic acid at $1 \mu \mathrm{M}$ did not change CerK activity; the values of CerK activity with the lipids were from 0.9- to 1.1-fold and from 3.1to 3.4-fold of control in the absence and presence of $0.1 \mathrm{~mm}$ $\mathrm{CaCl}_{2}$, respectively, which were similar as those without the lipids. $\mathrm{PI}(4,5) \mathrm{P}_{2}$ at $0.1 \mu \mathrm{M}$ had no effect, whereas the lipid at $1 \mu \mathrm{M}$ slightly inhibited CerK activity with $0.1 \mathrm{mM} \mathrm{CaCl}_{2}$ (Table 2): a relative CerK activity with $1 \mu \mathrm{M} \mathrm{PI}(4,5) \mathrm{P}_{2}$ was $82 \pm 8 \%$ ( $\%$ of the control without the lipid, $n=3$ ). Addition of $0.1 \mu \mathrm{M}$ cardiolipin (diphosphatidylglycerol) slightly stimulated CerK activity in the absence of $\mathrm{CaCl}_{2}$, but the responses were not significant (Figs. 2A, B). In the presence of $0.1 \mathrm{~mm} \mathrm{CaCl}_{2}$, cardiolipin showed a bell-shaped response that depended on the lipid concentrations: cardiolipin stimulated CerK activity from 0.05 to $0.1 \mu \mathrm{M}$ and inhibited it at concentrations greater than $0.5 \mu \mathrm{M}$. The activities of CerK with 1 and $5 \mu \mathrm{M}$ cardiolipin were significantly less than that with $0.1 \mu \mathrm{M}$. Cardiolipin at

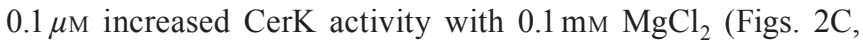
D). In the presence of $0.1 \mathrm{~mm} \mathrm{MgCl}_{2}$, the activity of CerK 
(A)

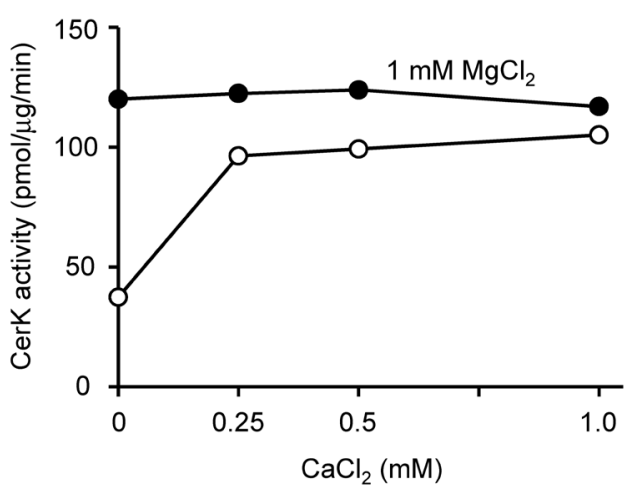

(B)

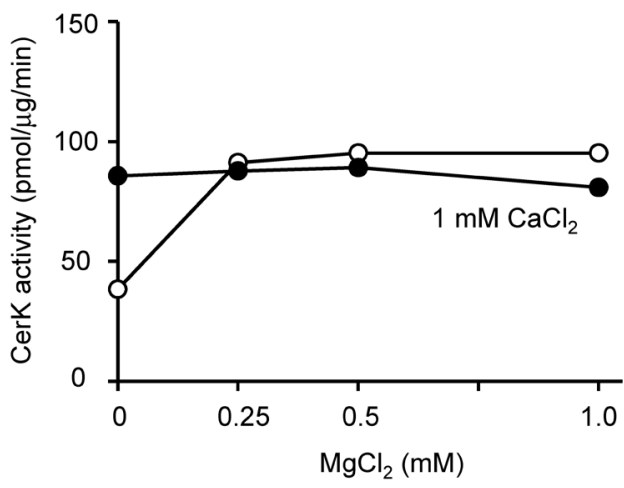

(C)

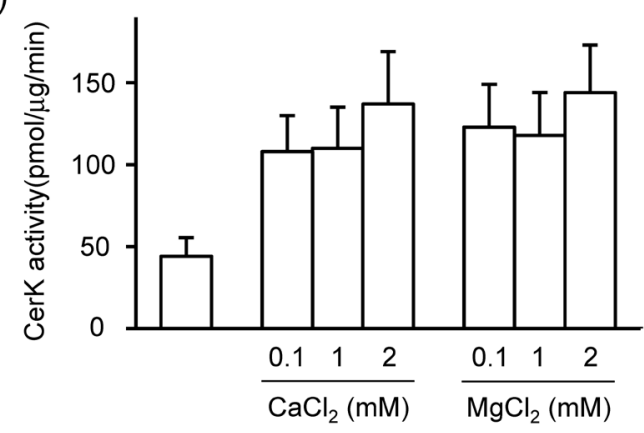

(D)

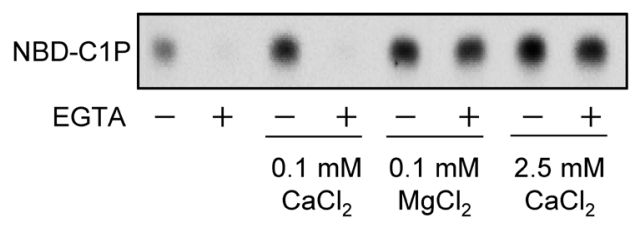

Fig. 1. Effects of $\mathrm{CaCl}_{2}, \mathrm{MgCl}_{2}$, and EGTA on Recombinant Human CerK Activity in the Glycerol/Albumin Buffer

CerK activity was measured with the indicated concentrations of $\mathrm{CaCl}_{2}$ or $\mathrm{MgCl}_{2}$. In (A) and (B), CerK activity was examined with $\mathrm{CaCl}_{2} / \mathrm{MgCl}_{2}$ alone (open circles) and in the presence of $\mathrm{MgCl}_{2}$ or $\mathrm{CaCl}_{2}$ at $1 \mathrm{~mm}$ (closed circles). Data are from a typical experiment, and images of TLC analyses were shown in Supplementary Fig. 1. Quantitative data are shown in (C). In (D), CerK activity was measured with the indicated concentrations of $\mathrm{CaCl}_{2} / \mathrm{MgCl}_{2}$. In some cases, assay mixtures were further supplemented with $2 \mathrm{~mm}$ EGTA. Data were from a typical representative experiment. Quantitative data for EGTA on CerK activity are shown in Table 1.

with $1 \mu \mathrm{M}$ cardiolipin was 1.6 - and 1.8-fold in two independent experiments, which were markedly less than that with $0.1 \mu \mathrm{M}$. Thus, cardiolipin appeared to show dual effects, stimulation with $0.1 \mu \mathrm{M}$ and inhibition with $1 \mu \mathrm{M}$, on CerK activity in the presence of $\mathrm{MgCl}_{2}$. We examined the effect of $0.1 \mu \mathrm{M}$ cardiolipin on the concentration-dependency of $\mathrm{CaCl}_{2}$ or $\mathrm{MgCl}_{2}$
Table 1. Effects of EGTA/EDTA on CerK Activity in the Glycerol/A1bumin Buffer and the Cardiolipin/Triton X-100 Buffer

\begin{tabular}{lccc}
\hline \hline \multirow{2}{*}{ Buffers } & None & EGTA & EDTA \\
\cline { 2 - 4 } & \multicolumn{3}{c}{ CerK activity (\%) } \\
\hline Glycerol/Albumin & 100 & $16.7 \pm 8.6$ & $2.1 \pm 0.5$ \\
Cardiolipon/Triton X-100 & 100 & $21.2 \pm 9.6$ & $2.4 \pm 0.4$ \\
\hline
\end{tabular}

CerK activity was measured with $2 \mathrm{~mm}$ EGTA or $2 \mathrm{~mm}$ EDTA in the glycerol/albumin buffer and cardiolipin/Triton X-100 buffer. $\mathrm{CaCl}_{2}$ and $\mathrm{MgCl}_{2}$ were not added to the reaction buffer in this experiment. Data were expressed as a percentage of control activity without EGTA/EDTA in the respective buffer, and are the mean \pm S.D. of three independent experiments.

Table 2. Effects of Glycerophospholipids on CerK Activity

\begin{tabular}{lcc}
\hline \hline & None & $\mathrm{CaCl}_{2}$ \\
\cline { 2 - 3 } & \multicolumn{2}{c}{ CerK activity (fold) } \\
\hline Vehicle & 1 & $3.2 \pm 0.4$ \\
$\mathrm{PA}$ & $1.2 \pm 0.4$ & $3.8 \pm 0.3$ \\
$\mathrm{PC}$ & $1.2 \pm 0.3$ & $3.3 \pm 0.3$ \\
$\mathrm{PE}$ & $1.1 \pm 0.2$ & $3.4 \pm 0.4$ \\
$\mathrm{PI}$ & $1.1 \pm 0.2$ & $3.2 \pm 0.3$ \\
$\mathrm{PS}$ & $1.2 \pm 0.2$ & $3.5 \pm 0.3$ \\
$\mathrm{PI}(4,5) \mathrm{P}_{2}$ & $1.2 \pm 0.2$ & $3.4 \pm 0.4$ \\
$\mathrm{PI}(4,5) \mathrm{P}_{2}(1 \mu \mathrm{M})$ & $1.1 \pm 0.1$ & $2.7 \pm 0.2$ \\
\hline
\end{tabular}

CerK activity was measured in the glycerol/albumin buffer with and without $0.1 \mathrm{~mm} \mathrm{CaCl}_{2}$. Vehicle, phosphatidic acid (PA), phosphatidylcholine (PC), phosphatidylethanolamine (PE), PI, phosphatidylserine (PS), and $\mathrm{PI}(4,5) \mathrm{P}_{2}$ at $0.1 \mu \mathrm{M}$ were added to the assay mixtures. In some cases, the effect of $1 \mu \mathrm{M} \mathrm{PI}(4,5) \mathrm{P}_{2}$ was examined. CerK activity was expressed as a fold of the control without $\mathrm{CaCl}_{2}$. Data are the mean \pm S.D. of three or four independent experiments.

from 0.01 to $0.1 \mathrm{~mm}$, and the lipid did not affect the sensitivity of CerK activity to $\mathrm{CaCl}_{2}$ and $\mathrm{MgCl}_{2}$ in a typical experiment (data not shown). These results demonstrated that cardiolipin, not other glycerophospholipids tested, directly affected CerK activity in vitro in the glycerol/albumin buffer containing $\mathrm{CaCl}_{2}$ or $\mathrm{MgCl}_{2}$.

Next, we examined CerK activity in the cardiolipin/Triton $\mathrm{X}-100$ buffer, and the basal activity and the $\mathrm{CaCl}_{2}-\mathrm{MgCl}_{2}$ responsibility in the buffer were compared with those in the glycerol/albumin buffer (Fig. 2E, Table 3). CerK activity was $26.7 \pm 2.9 \mathrm{pmol} / \mu \mathrm{g} / \mathrm{min}(n=7)$ without the exogenous addition of $\mathrm{CaCl}_{2} / \mathrm{MgCl}_{2}$ which was less than that in the glycerol/ albumin buffer, $44.1 \pm 11.4 \mathrm{pmol} / \mu \mathrm{g} / \mathrm{min}$. When CerK activity of a same recombinant CerK preparation was measured in the two buffers in an experiment, CerK activity in the cardiolipin/ Triton X-100 buffer was $40.1 \pm 9.2 \%$ of that in the glycerol/ albumin buffer $(p<0.05, n=3)$. CerK activity in the cardiolipin/Triton $\mathrm{X}-100$ buffer was increased by the addition of $\mathrm{CaCl}_{2}$ and $\mathrm{MgCl}_{2}$. Interestingly, the CerK activity with $1 \mathrm{~mm}$ $\mathrm{MgCl}_{2}$ in the cardiolipin/Triton X-100 buffer was two-fold of that in the glycerol/albumin buffer. The addition of $\mathrm{CaCl}_{2}$ at $10 \mu \mathrm{M}$ did not increase CerK activity $(20-30 \mathrm{pmol} / \mu \mathrm{g} / \mathrm{min})$, and the activity with $50 \mu \mathrm{M} \mathrm{CaCl}_{2}$ was approximately half of that with $0.1 \mathrm{~mm}$ in the cardiolipin/Triton X-100 buffer. The CerK activity with $\mathrm{CaCl}_{2} / \mathrm{MgCl}_{2}$ at both $1 \mathrm{~mm}$ was $0.84 \pm 0.21$ fold of that with $\mathrm{MgCl}_{2}$ alone $(n=3)$. Similar to the response in the glycerol/albumin buffer, CerK activity was markedly decreased in the presence of $2 \mathrm{~mm}$ EGTA and EDTA in the cardiolipin/Triton X-100 buffer (Table 1). In the cardiolipin/ Triton X-100 buffer, supplementation of glycerophospholipids 
(A)

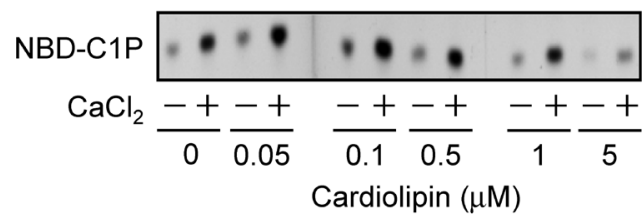

(B)

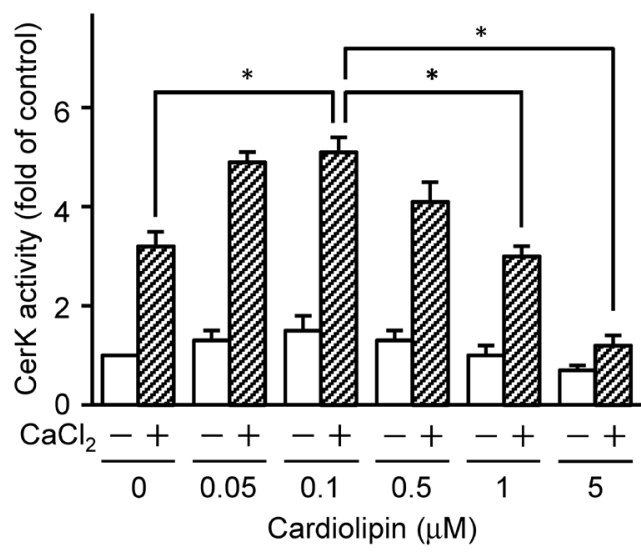

(C)

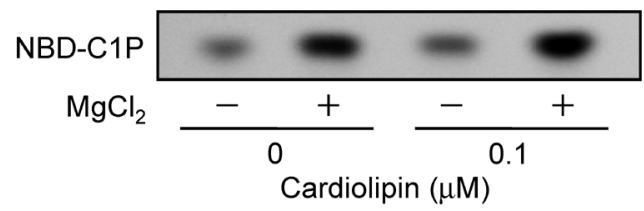

(D)

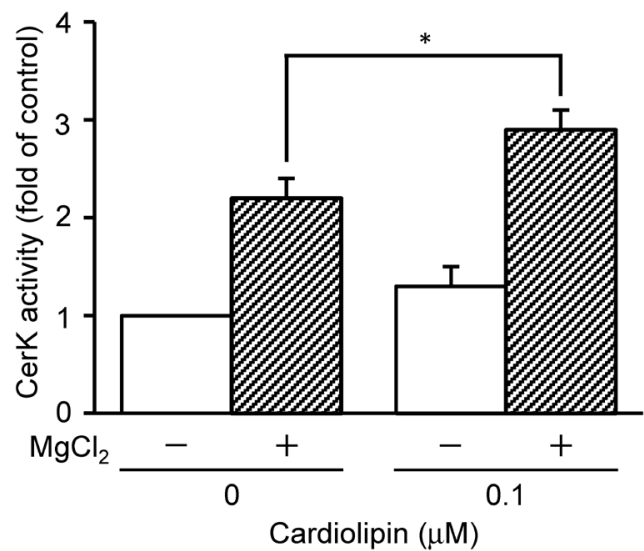

(E)

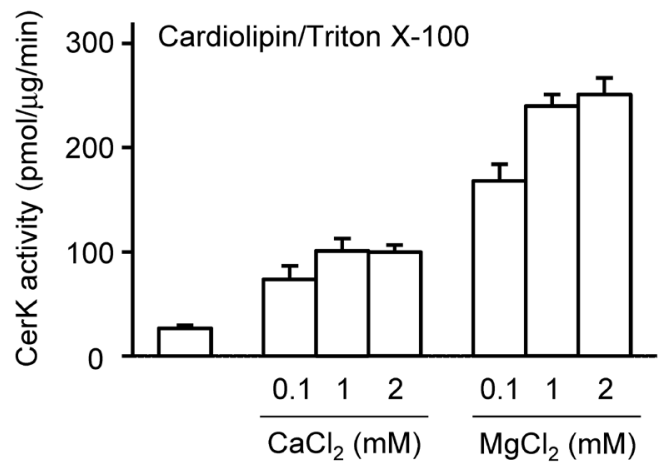

Fig. 2. Effect of Cardiolipin on CerK Activity

In (A)-(D), CerK activity was measured with the indicated concentrations of cardiolipin in the glycerol/albumin buffer. In some cases, assay mixtures were further supplemented with $0.1 \mathrm{~mm} \mathrm{CaCl}_{2}(\mathrm{~A}, \mathrm{~B})$ or $0.1 \mathrm{~mm} \mathrm{MgCl}_{2}(\mathrm{C}, \mathrm{D})$. Typical images of TLC analyses were shown in (A) and (C), and quantitative data were shown in (B) and (D). Data were expressed as a fold of the control without $\mathrm{CaCl}_{2} / \mathrm{MgCl}_{2}$, and are the mean \pm S.D. of three independent experiments. $* p<0.05$, significantly different between the two groups. In (E), CerK activity was measured with the indicated concentrations of $\mathrm{CaCl}_{2}$ or $\mathrm{MgCl}_{2}$ in the cardiolipin/Triton X-100 buffer. Data are the mean $\pm \mathrm{S}$. D. of three independent experiments.

Table 3. CerK Activity in the Glycerol/Albumin Buffer and the Cardiolipin/Triton X-100 Buffer

\begin{tabular}{|c|c|c|}
\hline \multirow{2}{*}{ Buffers } & Glycerol/Albumin & $\begin{array}{c}\text { Cardiolipin/Triton } \\
\text { X-100 }\end{array}$ \\
\hline & \multicolumn{2}{|c|}{ CerK activity (pmol/ $\mu \mathrm{g} / \mathrm{min})$} \\
\hline None & $44.1 \pm 11.4$ & $26.7 \pm 2.9$ \\
\hline $1 \mathrm{mM} \mathrm{CaCl}_{2}$ & $110 \pm 25$ & $101 \pm 12$ \\
\hline $1 \mathrm{mM} \mathrm{MgCl}_{2}$ & $118 \pm 26$ & $240 \pm 11$ \\
\hline \multirow[t]{2}{*}{$\mathrm{CaCl}_{2}$ and $\mathrm{MgCl}_{2}$} & \multicolumn{2}{|c|}{ CerK activity (fold of the value with $\mathrm{MgCl}_{2}$ ) } \\
\hline & $0.97 \pm 0.12$ & $0.84 \pm 0.21$ \\
\hline
\end{tabular}

Some data shown in Fig. 1C (the glycerol/albumin buffer) and Fig. 2E (cardiolipin Triton X-100 buffer) were summarized. CerK activity was measured with vehicle, $1 \mathrm{~mm} \mathrm{CaCl}_{2}, 1 \mathrm{~mm} \mathrm{MgCl}_{2}$, and the combination of $\mathrm{CaCl}_{2} / \mathrm{MgCl}_{2}$. The effects of combination of $\mathrm{CaCl}_{2} / \mathrm{MgCl}_{2}$ were expressed as a percentage of activity with $1 \mathrm{mM} \mathrm{MgCl}$ in the respective buffer, and are the mean \pm S.D. of three independent experiments.

such as $\mathrm{PI}(4,5) \mathrm{P}_{2}$ and cardiolipin at concentrations from 0.1 to $1 \mu \mathrm{M}$ did not change CerK activity (data not shown). The obtained data, regulation of CerK activity by cardiolipin in the in the glycerol/albumin buffer and a greater CerK activity in the cardiolipin/Triton $\mathrm{X}-100$ buffer with $\mathrm{MgCl}_{2}$ showed that cardiolipin affected the activity of human recombinant CerK.

Binding of Cardiolipin with CerK We employed another method to show the direct effect of cardiolipin on CerK: lipidprotein binding assays in two manners. In the lipid-protein overlay assay, cardiolipin bound to GST-CerK in a lipid concentration-dependent manner in the presence of $0.1 \mathrm{mM} \mathrm{CaCl}_{2}$ (Figs. 3A, B). PI(4,5) $\mathrm{P}_{2}$ and phosphatidic acid at $2 \mathrm{nmol}$ also bound to GST-CerK, as described previously. ${ }^{16,17)}$ Other glycerolipids tested did not bind to GST-CerK. Cardiolipin bound to GST- $\triangle$ PH-CerK (Fig. 3C), but not GST-PH-CerK (Fig. 3D) or the GST protein (Fig. 3E), under our conditions. Since divalent cations including $\mathrm{Ca}^{2+}$ may interact with the negatively charged head-group of cardiolipin, we examined the effects of $\mathrm{CaCl}_{2}$ on cardiolipin binding to CerK. The direct binding of cardiolipin to GST-CerK and GST- $\triangle \mathrm{PH}-\mathrm{CerK}$ was observed in the presence of $1 \mathrm{mM}$ EGTA without $\mathrm{CaCl}_{2}$ : the bindings of both proteins were approximately $80-90 \%$ of those with $0.1 \mathrm{mM} \mathrm{CaCl}_{2}$. The direct binding of cardiolipin to GST-CerK was examined in another lipid-protein binding assay, the large multilamellar vesicle binding assay (Fig. 3F). CerK bound to vesicles containing cardiolipin, but not phosphatidylcholine.

Possible Role of Cardiolipin on C1P Formation in Cells Choi et al. reported that over-expression of mitochondrial PLD6 caused a marked decrease in cardiolipin levels and that PLD6-GFP localized in mitochondria in NIH3T3 cells. $^{25)}$ Therefore, we attempted to regulate cardiolipin levels in HepG2 cells by transient transfection with the vector for PLD6-GFP (Fig. 4). The expression of PLD6-GFP was confirmed at the protein level (Fig. 4A). Choi et al. showed the localization of PLD6-GFP in the mitochondria in NIH3T3 


\section{(A) GST-Cerk}

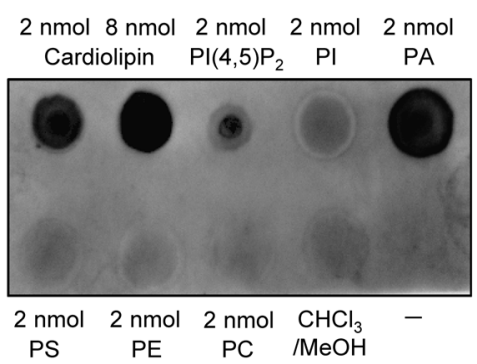

(B) GST-CerK

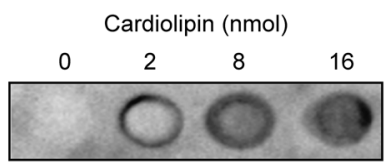

(D) GST-PH-CerK

Cardiolipin (nmol)

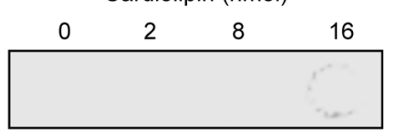

(C) GST- $\triangle \mathrm{PH}$-CerK

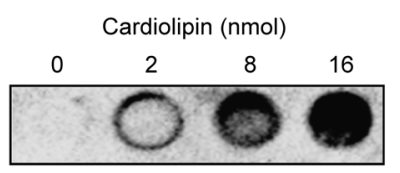

(E) GST

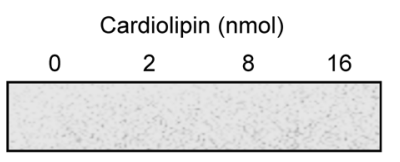

(F) GST-CerK/GST

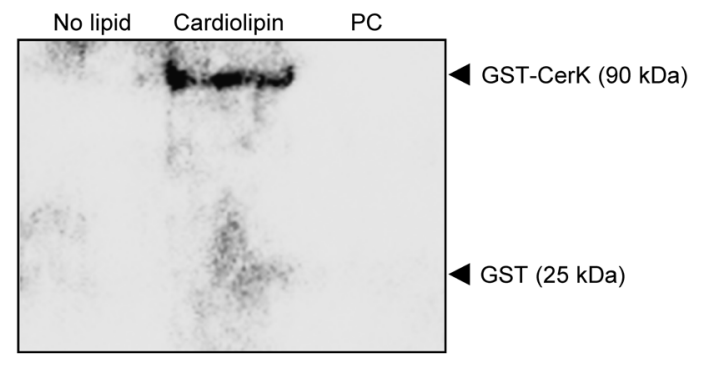

Fig. 3. Binding of Cardiolipin to CerK

The indicated amounts of cardiolipin, lipids, and the solvent were spotted onto a Hybond C membrane, and the lipid-protein overlay assay was performed. GST-CerK (A, B), GST- $\triangle$ PH-CerK (C), GST-PH-CerK (D), and GST (E) were used. In (F), the large multilamellar vesicle binding assay was performed. Vesicles of cardiolipin and phosphatidylcholine (PC) were incubated with GST-CerK and GST. Data are representative of three independent experiments.

cells. $^{25)}$ A similar intracellular localization of PLD6-GFP was observed in HepG2 cells (Fig. 4B). The cellular amounts of cardiolipin, but not those of other glycerophospholipids such as phosphatidylcholine and PI, were decreased in cells expressing PLD6-GFP (Fig. 4C). In cells expressing PLD6-GFP, cardiolpin level was $71 \%$ (\% of the control), and levels of PE, PI, PS, and PC were 98, 99, 102, and 103\%, respectively, in a typical experiment. Control HepG2 cells and HepG2 cells expressing PLD6-GFP were incubated with $10 \mu \mathrm{M}$ NBDceramide for $30 \mathrm{~min}$, and the levels of NBD-fluorescence in the extracted cellular lipids were analyzed. The formation of NBD-C1P was significantly less in HepG2 cells expressing PLD6-GFP than in the control cells (Figs. 4D, E). The formation of NBD-sphingomyelin was slightly but significantly less in HepG2 cells expressing PLD6-GFP than in control cells. Cellular levels of NBD-glucosylceramide, NBD-ceramide, and the endogenous CerK protein (data not shown) were almost the same in the two cells. These results suggest a probable stimulatory effect of endogenous cardiolipin on CIP formation. In contrast, cultivation of HepG2 cells with cardiolipin at greater concentrations over $10 \mu \mathrm{M}$ for $24 \mathrm{~h}$ showed an inhibitory effect on the formation of NBD-C1P (Fig. 5). The cardiolipin treatment did not appear to change amounts of NBDceramide taken up and other ceramide metabolites: for instance, the values of NBD-ceramide, NBD-glucosylceramide and NBD-sphingomyelin in $50 \mu \mathrm{m}$ caldiolipin-treated cells were $96-104 \%$ of the respective values in control cells. In a typical experiment, the levels of cardiolipin including the lipid attached to the cell membrane in HepG2 cells treated for $24 \mathrm{~h}$ with $50 \mu \mathrm{M}$ cardiolipin were $120-130 \%$ those of control cells without cardiolipin. The levels of other phospholipids such as phosphatidylcholine and PI were not changed by the cultivation of cells with cardiolipin (data not shown). We could not detect the stimulatory effects of cardiolipin exogenously added under our experimental conditions: the levels of NBD-C1P in
HepG2 cells incubated for $1 \mathrm{~h}$ with NBD-ceramide in the presence of $0.1-10 \mu \mathrm{M}$ cardiolipin were approximately $90 \%$ that of control cells without cardiolipin. The cultivation of HepG2 cells expressing PLD6-GFP for $24 \mathrm{~h}$ with $0.1-10 \mu \mathrm{M}$ cardiolipin did not reverse the decreased formation of $\mathrm{C} 1 \mathrm{P}$, and we could not examine the effects of caldiolipin at greater concentrations over $10 \mu \mathrm{M}$ on the cells because the cultivation caused cell detachment (data not shown). Over-expression of PLD6-GFP by itself and application of cardiolipin alone from 10 to $50 \mu \mathrm{M}$ for $24 \mathrm{~h}$ did not cause cell rounding and cell detachment (data not shown).

\section{DISCUSSION}

In the present study, we demonstrated that cardiolipin bound to CerK in vitro and showed diverse effects on CerK activity in vitro and in intact cells (a probable stimulation by endogenous cardiolipin and inhibition by exogenously added cardiolipin).

Binding of Cardiolipin to CerK in Vitro Cardiolipin is used as a molecule-stabilizing reagent in various assay systems in vitro, and has been shown to interact with various proteins possibly through the physical properties of the anionic lipid. ${ }^{28-30)}$ Also, activity of CerK was measured in cardiolipin-containing buffers in many previous reports. $1,19,20,22,23)$ However, direct evidence to show the physical association between cardiolipin and CerK as well as activation of this enzyme by the lipid does not currently exist. In the present study, we showed for the first time that cardiolipin directly bound to recombinant CerK in vitro using two lipid-protein binding assays, an overlay assay and large multilamellar vesicle binding assay (Fig. 3). In the lipid-protein overlay assay, cardiolipin bound to the full length of CerK and $\Delta \mathrm{PH}-\mathrm{CerK}$, but not PH-CerK. Previous studies reported that $\triangle \mathrm{PH}-\mathrm{CerK}$ has the capacity to bind to lipids. Carré et al. reported that 
(A)

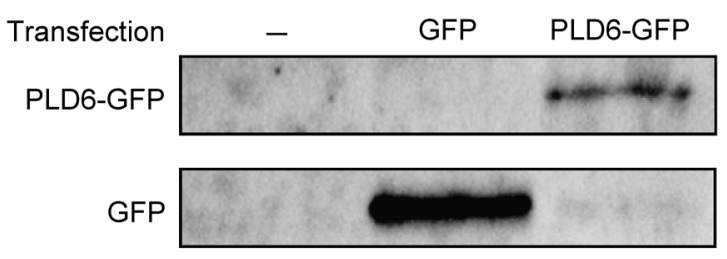

(B)

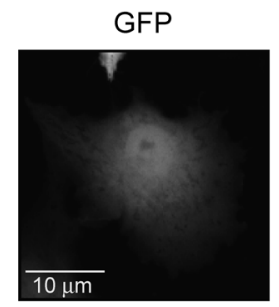

(D)
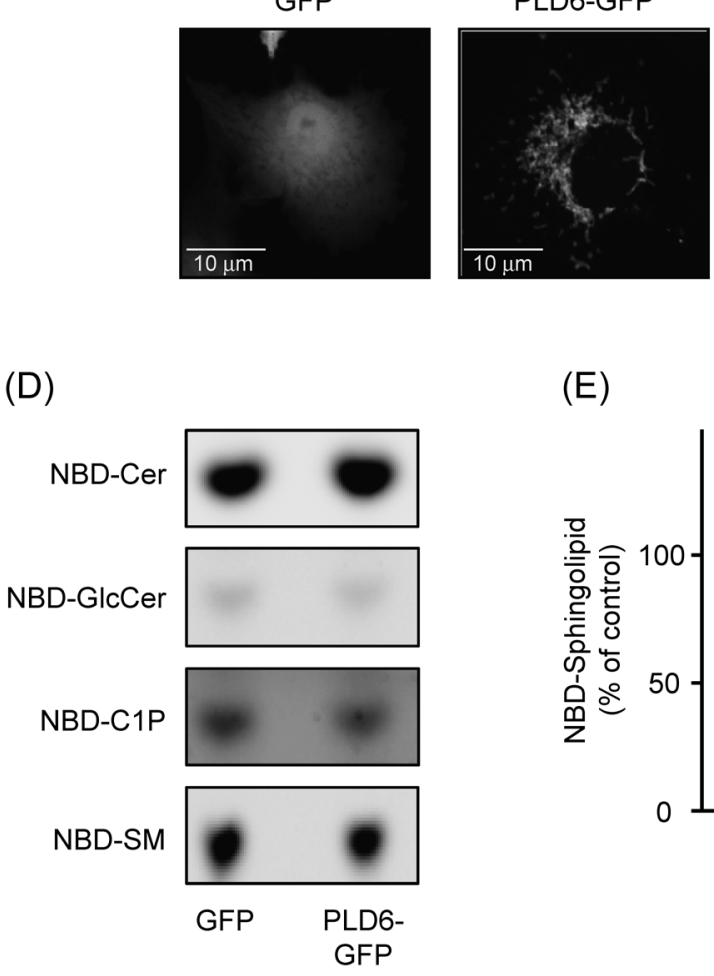

(E)
(C)

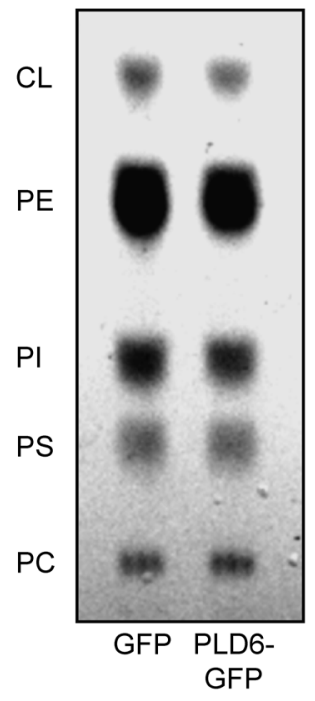

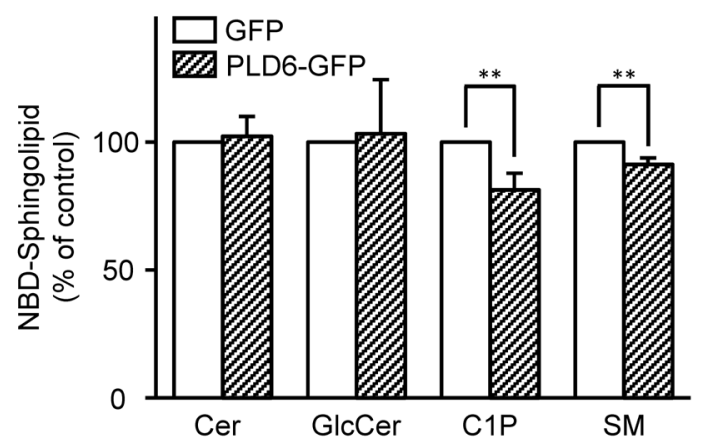

Fig. 4. Decreases in Cardiolipin Levels and NBD-C1P Formation in HepG2 Cells Over-Expressing PLD6

HepG2 cells were transiently tranfected with expression vectors for GFP and GFP-tagged PLD6, and cultured for 24h. (A) The expression of GFP and PLD6-GFP proteins was confirmed by Western blotting. (B) Green-fluorescence derived from the PLD6-GFP protein in cells was confirmed by confocal laser microscopy. (C) The phospholipids in cells were extracted, and separated on a TLC plate. Cardiolipin (CL), phosphatidylethanolamine (PE), PI, phosphatidylserine (PS), and phosphatidylcholine (PC). Data in (A), (B), and (C) are representative of two independent experiments. In (D) and (E), cells expressing GFP and PLD6-GFP were incubated with 10 $\mu$ M NBD-ceramide for $30 \mathrm{~min}$, and ceramide metabolites including NBD-C1P in wells (cells and medium) were extracted. Ceramide metabolites were separated by a TLC method. Typical images of NBD-ceramide and the metabolites on TLC plates were shown in (D), and quantitative data were shown in (E). NBD-ceramide (NBD-Cer, Cer), NBD-glucosylceramide (NBD-GlcCer, GlcCer), NBD-C1P (C1P), NBD-sphingomyelin (NBD-SM, SM). Data were expressed as percentages of respective NBDlabeled molecules in control cells expressing GFP alone. Data are the mean \pm S.D. of three independent experiments. $* * p<0.01$, significantly different from the control.

$\Delta \mathrm{PH}-\mathrm{CerK}$ exhibited slight, but distinct binding to liposomes of phospholipids containing phosphatidylethanolamine, phosphatidylcholine, and phosphatidylserine in a sucrose-loaded liposome assay; however, $\mathrm{PH}-\mathrm{CerK}$ strongly bound to the liposomes. ${ }^{15)} \mathrm{Kim}$ et al. reported that $\mathrm{PI}(4,5) \mathrm{P}_{2}$ mainly bound to $\mathrm{PH}-\mathrm{CerK}$, but other poly-phosphorylated PIs including PI 3-phosphate bound to CerK via the non-PH domain of CerK. ${ }^{16}$ ) Rovina et al. reported that $\mathrm{PI}(4,5) \mathrm{P}_{2}$ bound to the C-terminally FLAG-tagged CerK, but not to the C-terminally FLAG-tagged $\mathrm{PH}$ domain of CerK, in a similar lipid-protein overlay assay. ${ }^{17}$ ) In addition to $\mathrm{PH}$ domain, poly-phosphorylated forms of PI including $\mathrm{PI}(4,5) \mathrm{P}_{2}$ have been shown to bind to various domains having basic motifs in proteins. ${ }^{31)}$ These results including ours suggest that CerK may have multiple binding domains of the lipids such as cardiolipin and $\mathrm{PI}(4,5) \mathrm{P}_{2}$. The exact domains and/or amino acids of CerK responsible for cardiolipin binding have yet to be identified.

Regulation of CerK Activity by Cardiolipin in Vitro Both $\mathrm{PI}(4,5) \mathrm{P}_{2}$ and phosphatidic acid were shown to bind to CerK. ${ }^{16,17)}$ It was reported that $\mathrm{PI}(4,5) \mathrm{P}_{2}$ did not change CerK activity, ${ }^{16)}$ while the effect of phosphatidic acid on the activity has not yet been demonstrated. We confirmed the binding of CerK to $\mathrm{PI}(4,5) \mathrm{P}_{2}$ and phosphatidic acid (Fig. 3A). Under our conditions, supplementation with $\mathrm{PI}(4,5) \mathrm{P}_{2}$ and phosphatidic acid at $0.1 \mu \mathrm{M}$ did not change CerK activity, although $1 \mu \mathrm{M}$ $\mathrm{PI}(4,5) \mathrm{P}_{2}$ slightly inhibit the activity. Other glycerophospholipids including PI and phosphatidylcholine did not change CerK activity with or without $0.1 \mathrm{~mm} \mathrm{CaCl}_{2}$ (Table 2). Interestingly, we found that cardiolipin had diverse effects on CerK activity in vitro: cardiolipin at $0.1 \mu \mathrm{M}$ significantly increased CerK activity, whereas the lipid at concentrations greater than $1 \mu \mathrm{M}$ had inhibitory effects in the glycerol/albumin buffer. Thus, 
(A)

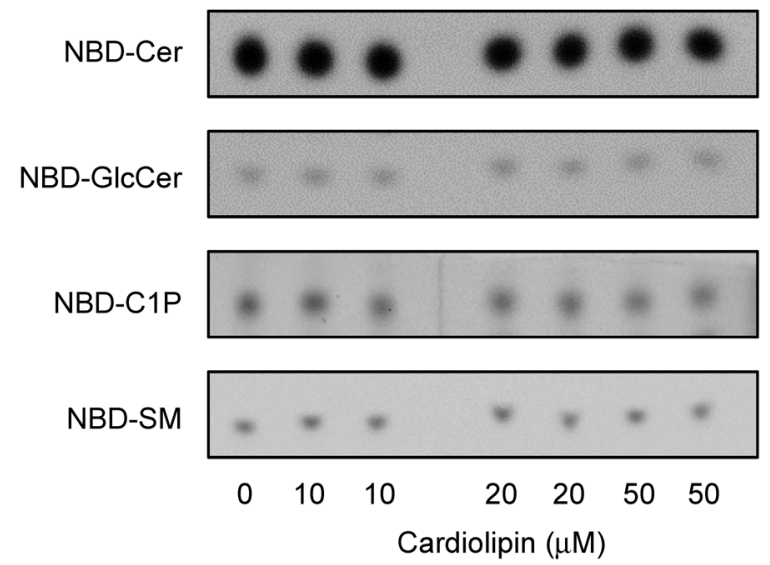

(B)

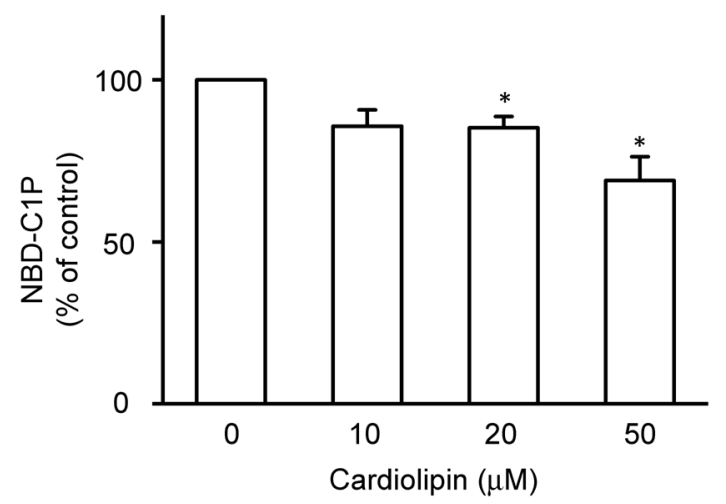

Fig. 5. Decreased Formation of NBD-C1P in Cardiolipin-Treated HepG2 Cells

HepG2 cells were cultured with cardiolipin at the indicated concentrations for $24 \mathrm{~h}$, and the cells after washing were incubated with $10 \mu \mathrm{M}$ NBD-ceramide for $1 \mathrm{~h}$. Typical images of NBD-ceramide metabolites on the TLC plate were shown in (A), and quantitative data for NBD-C1P formation were shown in (B). Data were expressed as a percentage of NBD-C1P levels in the control cells, and are the mean \pm S.E.M. of three independent experiments performed in duplicate. ${ }^{*} p<0.05$, significantly different from the control.

cardiolipin appeared to be the first case for the direct regulation of CerK by glycerophospholipids. The concentration dependency of $\mathrm{CaCl}_{2}$ and $\mathrm{MgCl}_{2}$ in the cardiolipin/Triton X-100 buffer (Fig. 2E) was almost the same as that in the glycerol/ albumin buffer (Fig. 1C), and the addition of cardiolipin did not appear to change this dependency in the glycerol/albumin buffer. CerK activity without $\mathrm{CaCl}_{2} / \mathrm{MgCl}_{2}$ in the cardiolipin/Triton X-100 buffer was significantly less than that in the glycerol/albumin buffer, and its activity with $1 \mathrm{~mm} \mathrm{CaCl}_{2}$ was almost the same in the two buffers (Figs. 1C, 2E). Thus, cardiolipin at concentrations that had a stimulatory effect on CerK appeared to increase intrinsic activity of the enzyme. CerK activity showed a greatest value with $\mathrm{MgCl}_{2}$ in the cardiolipin/Triton X-100 buffer containing $36 \mu \mathrm{m}$ cardiolipin, and the lipid at $0.1 \mu \mathrm{M}$ increased CerK activity with $\mathrm{MgCl}_{2}$ in the glycerol/albumin buffer. Although it was difficult to compare the concentration dependency of cardiolipin in the two buffers because of Triton X-100 and/or glycerol, caldiolipin appeared to increase CerK activity in vitro. Cardiolipin was reported to increase intrinsic activity of mitochondrial-associated neutral sphingomyelinase. ${ }^{32)}$ It remains to be solved how cardiolipin acts as a bi-directional regulator of CerK activity in vitro (and in intact cells). In the present study, we used cardiolipin ex- tracted from bovine heart. Alteration in its acyl chain composition and peroxidation of cardiolipin have been proposed to show different effects in tissues-dependent manner. ${ }^{33,34)}$ Precise mechanisms to explain the biphasic regulation of CerK and/or C1P formation by cardiolipin including specificity of molecular forms of cardiolipin remain to be elucidated.

Regulation of CerK Activity by Cardiolipin in Cells In the present study, a deviation from the normal range of cardiolipin, both the decrease by PLD6 expression and increase by an exogenous addition of the lipid, negatively regulated C1P formation in intact cells, although we could not have a direct evidence showing a stimulatory effect of cardiolipin. CerK was mainly detected in the plasma membranes, Golgi complex, and endosomes in cells, ${ }^{1,4,19,21)}$ although the localization of CerK in the cytosol was reported in rat basophilic leukemia (RBL-CK3) cells. ${ }^{10)}$ CerK appeared to be attached to the cytosolic face of the cellular organelles including the plasma membranes. ${ }^{4,21)}$ Cardiolipin, which is mainly formed in the matrix of mitochondria and is, thus, extensively found in mitochondrial membranes. How and/where cardiolipin interacts with CerK in cells ? In the present study, we showed that the formation of NBD-C1P was reduced in HepG2 cells expressing mitochondrial PLD6 and showing low cardiolipin levels (Fig. 4). Since the CerK protein and its activity have been shown to exist, at least partially, within mitochondria in A549 lung adenocarcinoma cells, ${ }^{21)}$ cardiolipin existing endogenously in cells may stimulate CerK in the mitochondria. However, we could not observe a marked mitochondrial association of the C-terminally GFP-tagged CerK in HepG2 cells, like in CHO cells. ${ }^{35)}$ The pre-treatment of HepG2 cells with cardiolipin for $24 \mathrm{~h}$ significantly inhibited the formation of NBD-C1P (Fig. 5). Exogenously added cardiolipin was shown to move to mitochondria through a fusion process between this lipid and the plasma membrane in glioblastoma cells, ${ }^{36}$ and the dynamic cellular movement of cardiolipin has been proposed between mitochondria and other organelles including endosomes in cells. ${ }^{28,37)}$ Enzymes for ceramide-related pathways including sphingosine kinases $1 / 2$ were activated by cardiolipin in vitro, ${ }^{32,38-43)}$ and many enzymes of the pathway exist in non-mitochondrial compartments such as the plasma membrane and endosomes. A probable intracellular movement of cardiolipin and/or a transient localization of cardiolipin may explain the interaction of ceramide metabolic enzymes including CerK and cardiolipin in the non-mitochondrial compartments in cells. Identification of intracellular compartments for cardiolipin-CerK interaction remains to be elucidated. Alterations of cardiolipin in cells have been shown to be involved in various pathological conditions including ischemia, hypothyroism, Barth syndrome, and aging, etc. ${ }^{33,34)}$ Also, CerK and C1P appear to be involved in ischemia and neurodegenerative diseases. $^{41,42)}$ Possible interactions between cardiolipin and CerK/C1P should be determined physiologically and pathologically.

Effects of $\mathrm{Ca}^{2+}$ and $\mathrm{Mg}^{2+}$ on CerK Activity In the present study, the addition of $\mathrm{CaCl}_{2}$ increased CerK activity in both the glycerol/albumin and cardiolipin/Triton X-100 buffers (Figs. 1,2). The addition of $2 \mathrm{~mm}$ EGTA markedly decreased CerK activity with $0.1 \mathrm{~mm} \mathrm{CaCl}$, without changing its activity with $0.1 \mathrm{~mm} \mathrm{MgCl}_{2}$ in the glycerol/albumin buffer (Fig. 1D). These results suggested the selective trapping of $\mathrm{Ca}^{2+}$ by EGTA and were consistent with previous findings showing 
that CerK was a $\mathrm{Ca}^{2+}$-dependent enzyme. ${ }^{1-3)}$ Under our conditions, the addition of $\mathrm{CaCl}_{2}$ up to $10 \mu \mathrm{M}$ did not increase CerK activity in either buffer. Similar findings were reported in immunoprecipitated CerK activity from rat basophilic leukemia cells. ${ }^{10)}$ The addition of $\mathrm{MgCl}_{2}$ increased CerK activity without $\mathrm{CaCl}_{2}$ in both buffers (Figs. 1C, 2E). Since the addition of $0.1 \mathrm{mM} \mathrm{MgCl}_{2}$ increased CerK activity in the presence of EGTA, $\mathrm{MgCl}_{2}$ appeared to have stimulatory effects on CerK activity in a $\mathrm{Ca}^{2+}$-independent manner. The results obtained in vitro suggested that either $\mathrm{CaCl}_{2}$ or $\mathrm{MgCl}_{2}$, possibly the divalent cations, $\mathrm{Ca}^{2+}$ or $\mathrm{Mg}^{2+}$, was essential for CerK activity. In the cardiolipin/Triton X-100 buffer, the addition of $1 \mathrm{~mm}$ $\mathrm{MgCl}_{2}$ alone increased CerK activity by 8 -fold, which was much greater than that by $1 \mathrm{mM} \mathrm{CaCl}_{2}$, and the co-addition of $\mathrm{CaCl}_{2}-\mathrm{MgCl}_{2}$ did not show additive and/or synergic effects. The results were consistent with those in a previous report by Van Overloop et al. ${ }^{19)}$ In kinase reactions, divalent cations such as $\mathrm{Mg}^{2+}$ and $\mathrm{Ca}^{2+}$ interact and reduce negative charges in the phosphate groups of ATP, and may generally enhance the transfer of phosphate groups to substrates and the association between enzymes and ATP. Previous findings and the present results suggest that $\mathrm{Ca}^{2+}$ is not a direct activator of CerK, while divalent cations such as $\mathrm{Mg}^{2+}$ and $\mathrm{Ca}^{2+}$ appear to be essential factors for a kinase reaction of CerK. Mitsutake and Igarashi reported that calmodulin bound to CerK, which resulted in the $\mathrm{Ca}^{2+}$-dependent activation of CerK. ${ }^{43}$ The regulatory mechanisms of $\mathrm{Ca}^{2+}$ on CerK including roles of $\mathrm{Ca}^{2+}$-binding proteins such as calmodulin and calcineurin on the enzyme have yet to be established.

Acknowledgments We thank Dr. Takafumi Kohama (Daiichi-Sankyo, Tokyo, Japan) and Prof. A. Nishida (Chiba University, Japan) for providing the vector for human CerK and NBD-ceramide, respectively. These studies were partially supported by Grants-in-Aid (24790066, 26460060 to H.N. and 26460093 to T.M.) from the Ministry of Education, Culture, Sports, Science and Technology (MEXT) of Japan.

Conflict of Interest The authors declare no conflict of interest.

Supplementary Materials The online version of this article contains supplementary materials.

\section{REFERENCES}

1) Sugiura M, Kono K, Liu H, Shimizugawa T, Minekura H, Spiegel S, Kohama T. Ceramide kinase, a novel lipid kinase: molecular cloning and functional characterization. J. Biol. Chem., 277, 2329423300 (2002).

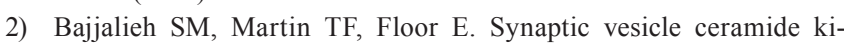
nase: a calcium-stimulated lipid kinase that co-purifies with brain synaptic vesicles. J. Biol. Chem., 264, 14354-14360 (1989).

3) Kolesnick RN, Hemer MR. Characterization of a ceramide kinase activity from human leukemia (HL-60) cells. Separation from diacylglycerol kinase activity. J. Biol. Chem., 265, 18803-18808 (1990).

4) Bornancin F. Ceramide kinase: the first decade. Cell. Signal., 23, 999-1008 (2011).

5) Hoeferlin LA, Wijesinghe DS, Chalfant CE. The role of ceramide1-phosphate in biological functions. Handb. Exp. Pharmacol., 215, 153-166 (2013).
6) Gomez-Muñoz A, Gangoiti P, Arana L, Ouro A, Rivera IG, Ordoñez M, Trueba M. New insights on the role of ceramide 1-phosphate in inflammation. Biochim. Biophys. Acta, 1831, 1060-1066 (2013).

7) Bajjalieh S, Batchelor R. Ceramide kinase. Methods Enzymol., 311, 207-215 (2000).

8) Boath A, Graf C, Lidome E, Ullrich T, Nussbaumer P, Bornancin F. Regulation and traffic of ceramide-1-phosphate produced by ceramide kinase: comparative analysis to glucosylceramide and sphingomyelin. J. Biol. Chem., 283, 8517-8526 (2008).

9) Pettus BJ, Bielawska A, Spiegel S, Roddy P, Hunnun YA, Chalfant CE. Ceramide kinase mediates cytokine- and calcium ionophoreinduced arachidonic acid release. J. Biol. Chem., 278, 38206-38213 (2003).

10) Mitsutake S, Kim TJ, Inagaki Y, Kato M, Yamashita T, Igarashi Y. Ceramide kinase is a mediator of calcium-dependent degranulation in mast cells. J. Biol. Chem., 279, 17570-17577 (2004).

11) Shimizu M, Tada E, Makiyama T, Yasufuku K, Moriyama Y, Fujino H, Nakamura H, Murayama T. Effects of ceramide, ceramidases inhibition and expression of ceramide kinase on cytosolic phospholipase $\mathrm{A}_{2} \alpha$ : additional role of ceramide-1-phosphate in phosphorylation and $\mathrm{Ca}^{2+}$ signaling. Cell. Signal., 21, 440-447 (2009).

12) Lidome E, Graf C, Jaritz M, Schanzer A, Rovina P, Nikolay R, Bornancin F. A conserved cysteine motif essential for ceramide kinase function. Biochimie, 90, 1560-1565 (2008).

13) Chen WQ, Graf C, Zimmel D, Rovina P, Krapfenbauer K, Jaritz M, Parker PJ, Lubec G, Bornancin F. Ceramide kinase profiling by mass spectrometry reveals a conserved phosphorylation pattern downstream of the catalytic site. J. Proteome Res., 9, 420-429 (2010).

14) Tada E, Toyomura K, Nakamura H, Sasaki H, Saito T, Kaneko M, Okuma Y, Murayama T. Activation of ceramidase and ceramide kinase by vanadate via a tyrosine kinase-mediated pathway. J. Pharmacol. Sci., 114, 420-432 (2010).

15) Carré A, Graf C, Stora S, Mechtcheriakova D, Csonga R, Urtz N, Billich A, Baumruker T, Bornancin F. Ceramide kinase targeting and activity determined by its N-terminal pleckstrin homology domain. Biochem. Biophys. Res. Commun., 324, 1215-1219 (2004).

16) Kim TJ, Mitsutake S, Igarashi Y. The interaction between the pleckstrin homology domain of ceramide kinase and phosphatidylinositol 4,5-bisphosphate regulates the plasma membrane targeting and ceramide 1-phosphate levels. Biochem. Biophys. Res. Commun., 342, 611-617 (2006).

17) Rovina P, Jaritz M, Höfinger S, Graf C, Dévay P, Billich A, Baumruker T, Bornancin F. A critical $\beta 6-\beta 7$ loop in the pleckstrin homology domain of ceramide kinase. Biochem. J., 400, 255-265 (2006).

18) Rovina P, Schanzer A, Graf C, Mechtcheriakova D, Jaritz M, Bornancin F. Subcellular localization of ceramide kinase and ceramide kinase-like protein requires interplay of their pleckstrin homology domain-containing N-terminal regions together with C-terminal domains. Biochim. Biophys. Acta, 1791, 1023-1030 (2009).

19) Van Overloop H, Gijsbers S, Van Veldhoven PP. Further characterization of mammalian ceramide kinase: substrate delivery and (stereo)specificity, tissue distribution, and subcellular localization studies. J. Lipid Res., 47, 268-283 (2006).

20) Wijesinghe DS, Lamour NF, Gomez-Munoz A, Chalfant CE. Ceramide kinase and ceramide-1-phosphate. Methods Enzymol., 434, 265-292 (2007).

21) Lamour NF, Stahelin RV, Wijesinghe DS, Maceyka M, Wang E, Allegood JC, Merrill AH Jr, Cho W, Chalfant CE. Ceramide kinase uses ceramide provided by ceramide transport protein: localization to organelles of eicosanoid synthesis. J. Lipid Res., 48, 1293-1304 (2007)

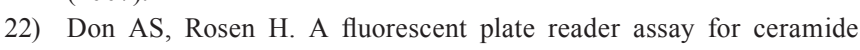
kinase. Anal. Biochem., 375, 265-271 (2008).

23) Don AS, Rosen H. A lipid binding domain in sphingosine kinase 2. Biochem. Biophys. Res. Commun., 380, 87-92 (2009). 
24) Nakamura H, Moriyama $Y$, Makiyama $T$, Emori S, Yamashita H, Yamazaki R, Murayama T. Lactosylceramide interacts with and activates cytosolic phospholipase $\mathrm{A}_{2} \alpha$. J. Biol. Chem., 288, 2326423272 (2013).

25) Choi SY, Huang P, Jenkins GM, Chan DC, Schiller J, Frohman MA. A common lipid links Mfn-mediated mitochondrial fusion and SNARE-regulated exocytosis. Nat. Cell Biol., 8, 1255-1262 (2006).

26) Sasaki H, Toyomura H, Matsuzaki W, Okamoto A, Yamaguchi $\mathrm{N}$, Nakamura $\mathrm{H}$, Murayama T. Regulation of alkaline ceramidase activity by the c-Src-mediated pathway. Arch. Biochem. Biophys., 550-551, 12-19 (2014)

27) Makiyama $T$, Nakamura $H$, Nagasaka $N$, Yamashita $H$, Honda $T$, Yamaguchi N, Nishida A, Murayama T. Trafficking of acetyl-C16ceraide-NBD with long-term stability and no cytotoxicity into the Golgi complex. Traffic, 16, 476-492 (2015).

28) Tamura Y, Sesaki H, Endo T. Phospholipid transport via mitochondria. Traffic, 15, 933-945 (2014).

29) Schlame M, Rua D, Greenberg ML. The biosynthesis and functional role of cardiolipin. Prog. Lipid Res., 39, 257-288 (2000).

30) Yamamoto K, Miyazaki K, Higashi S. Pericellular proteolysis by matrix metalloproteinase-7 is differently modulated by cholesterol sulfate, sulfatide, and cardiolipin. FEBS J., 281, 3346-3356 (2014).

31) Stahelin RV, Scott JL, Frick CT. Cellular and molecular interactions of phosphoinositides and peripheral proteins. Chem. Phys. Lipids, 182, 3-18 (2014)

32) Wu BX, Rajagopalan V, Roddy PL, Clarke CJ, Hannun YA. Identification and characterization of murine mitochondria-associated neutral sphingomyelinase (MA-nSMase), the mammalian sphingomyelin phosphodiesterase 5. J. Biol. Chem., 285, 17993-18002 $(2010)$.

33) Chicco AJ, Sparagna GC. Role of cardiolipin alterations in mitochondrial dysfunction and disease. Am. J. Physiol. Cell Physiol., 292, C33-C44 (2007).

34) Ren M, Phoon CK, Schlame M. Metabolism and function of mito- chondrial cardiolipin. Prog. Lipid Res., 55, 1-16 (2014).

35) Nakamura H, Tada E, Makiyama T, Yasufuku K, Murayama T. Role of cytosolic phospholipase $A_{2} \alpha$ in cell rounding and cytotoxicity induced by ceramide-1-phosphate via ceramide kinase. Arch. Biochem. Biophys., 512, 45-51 (2011).

36) Buratta M, Castigli E, Sciaccaluga M, Pellegrino RM, Spinozzi $F$, Roberti R, Corazzi L. Loss of cardiolipin in palmitate-treated GL15 glioblastoma cells favors cytochrome $c$ release from mitochondria leading to apoptosis. J. Neurochem., 105, 1019-1031 (2008).

37) Sorice M, Circella A, Cristea IM, Garofalo T, Di Renzo L, Alessandri C, Valesini G, Esposti MD. Cardiolipin and its metabolites move from mitochondria to other cellular membranes during death receptor-mediated apoptosis. Cell Death Differ., 11, 1133-1145 (2004).

38) Marchesini N, Luberto C, Hannun YA. Biochemical properties of mammalian neutral sphingomyelinase2 and its role in sphingolipid metabolism. J. Biol. Chem., 278, 13775-13783 (2003).

39) Olivera A, Rosenthal J, Spiegel S. Effect of acidic phospholipids on sphingosine kinase. J. Cell. Biochem., 60, 529-537 (1996).

40) Kita K, Sueyoshi N, Okino N, Inagaki M, Ishida H, Kiso M, Imayama S, Nakamura T, Ito M. Activation of bacterial ceramidase by anionic glycerophospholipids: possible involvement in ceramide hydrolysis on atopic skin by Pseudomonas ceramidase. Biochem. J., 362, 619-626 (2002).

41) Yuyama K, Mitsutake S, Igarashi Y. Pathological roles of ceramide and its metabolites in metabolic syndrome and Alzheimer's disease. Biochim. Biophys. Acta, 1841, 793-798 (2014).

42) Nagareddy PR, Asfour A, Klyachkin YM, Abdel-Latif A. A novel role for bioactive lipids in stem cell mobilization during cardiac ischemia. J. Thromb. Thrombolysis, 37, 24-31 (2014).

43) Mitsukate S, Igarashi Y. Calmodulin is involved in the $\mathrm{Ca}^{2+}$ dependent activation of ceramide kinase as a calcium sensor. $J$. Biol. Chem., 280, 40436-40441 (2005). 